\title{
EFFECT OF ROUX-EN-Y GASTRIC BYPASS IN THE CONTROL OF EROSIVE ESOPHAGITIS
}

\author{
Antônio Benincá Albuquerque ${ }^{1}$, \\ André Luca Boeira Rovani ${ }^{1}$, Bruna Schmitt Puhl ${ }^{1}$, \\ Carlos Roberto Giacometti', Eduardo Dombroski da Silva', \\ Elisa Estivalete Jablonski', Fernanda Marcante Carlotto', \\ Fernanda Tisott Burtet ${ }^{1}$, Jaline Ribeiro da Silva ${ }^{1}$, Larissa Belke ${ }^{1}$, \\ Carlos Augusto Scussel Madalosso ${ }^{2,3}$, Daniel Navarini ${ }^{1,2,3}$
}

Clin Biomed Res. 2019;39(2):136-139

1 Faculdade de Medicina, Universidade de Passo Fundo (UPF). Passo Fundo, RS, Brasil.

2 Departamento de Cirurgia, Hospital São Vicente de Paulo (HSVP). Passo Fundo, RS, Brasil.

3 Departamento de Cirurgia, Clínica Gastrobese. Passo Fundo, RS, Brasil.

Corresponding author:

Daniel Navarini

danielnavarini@hotmail.com

Faculdade de Medicina, Universidade de Passo Fundo (UPF)

Av. Brasil Leste, 285.

99052-900, Passo Fundo, RS, Brasil.

\section{ABSTRACT}

Introduction: Gastroesophageal reflux disease (GERD) is a multifactorial disease associated with environmental and genetic factors. Obesity is among the risk factors for its development, which also correlates with an increase in severity of clinical presentation and a higher incidence of complications associated with reflux.

Methods: This historical cohort study included a sample of 249 patients who had undergone bariatric surgery using the Roux-en- $Y$ gastric bypass technique at the Hospital São Vicente de Paulo, Passo Fundo, southern Brazil, from January 2014 to December 2015.

Results: Of 249 patients, $77.9 \%$ (190 patients) were female and the mean age was 38 years. The occurrence of reflux esophagitis was $81.1 \%$ (196 patients) in the preoperative period and $31.3 \%$ (75 patients) in the postoperative period. With regard to bariatric treatment response to control moderate and severe esophagitis (grades B, C and D), there was a reduction in prevalence from $62(25 \%)$ to $12(5 \%)$ patients $(p<0.05)$.

Conclusions: Bariatric surgery using the Roux-en-Y gastric bypass technique is effective in the control of reflux esophagitis. Regression is observed mainly in cases of moderate and severe esophagitis.

Keywords: Erosive esophagitis; GERD; bariatric surgery; obesity; comorbidity

Gastroesophageal reflux disease (GERD) is a multifactorial disease associated with environmental and genetic factors. Obesity is among the risk factors for its development, which also correlates with an increase in severity of clinical presentation and a higher incidence of complications associated with reflux ${ }^{1,2}$. Its prevalence distribution is quite variable in the world and depends on multiple factors, including eating behaviors, prevalence of obesity, smoking, and use of non-steroidal anti-inflammatory drugs ${ }^{3}$.

There are several mechanisms by which obesity interferes in the occurrence of GERD. Weight gain increases abdominal pressure and, consequently, intragastric pressure, besides promoting changes in the gastroesophageal pressure gradient. It also leads to changes in the integrity of the esophagogastric junction and cranial displacement of the lower esophageal sphincter (LES), with possible formation of hiatal hernia. Hiatal hernia is a known cause of GERD and is four times more common in obese people. Among the obese population there is also a higher prevalence of esophagitis, occurring more frequently in white patients when compared to black patients ${ }^{4-7}$. The aim of this study was to evaluate the impact of Roux-en-Y gastric bypass on the control of erosive esophagitis and metabolic and anthropometric parameters related to obesity. 


\section{MATERIALS AND METHODS}

This retrospective cohort study included 249 patients who underwent bariatric surgery using the Roux-en-Y gastric bypass technique at the Hospital São Vicente de Paulo (HSVP), southern Brazil, from January 2014 to December 2015. The primary variables were analyzed in the preoperative and postoperative period between 6 and 12 months. Laboratory tests, upper digestive endoscopy, abdominal ultrasonography, anthropometric evaluation and body composition analysis by bioelectrical impedance were evaluated in order to analyze the impact of Roux-en-Y gastric bypass on reflux esophagitis. The secondary variables were weight loss, lean body mass increase, hepatic steatosis, level of high-density lipoprotein (HDL) cholesterol, level of low-density lipoprotein (LDL) cholesterol and total cholesterol.

Reflux esophagitis endoscopic evaluation was based on the Los Angeles Grading of Esophagitis as follows: grade A: mucosal break no longer than $5 \mathrm{~mm}$ that does not extend between the tops of two mucosal folds; grade B: mucosal break longer than $5 \mathrm{~mm}$ long that does not extend between the tops of two mucosal folds; grade C: mucosal break that is continuous between the tops of two or more mucosal folds but involving less than $75 \%$ of the esophageal circumference; and grade D: mucosal break involving at least $75 \%$ of the esophageal circumference. Esophagitis improvement was determined by comparing Los Angeles Grading of Esophagitis grades on preoperative and postoperative upper digestive endoscopies.

Gastric bypass was performed with mechanical stapling, forming a gastric pouch with $30-\mathrm{mL}$ capacity, a biliopancreatic limb length of $80 \mathrm{~cm}$ and an alimentary limb length of $100 \mathrm{~cm}$. The diameter of the gastrojejunal anastomosis was $1.2 \mathrm{~cm}$, and a Fouchet probe was used for calibration.

The data were entered into an Excel spreadsheet (Microsoft, United States). Statistical analysis was performed using SPSS statistical software, version 20.0. In all analyses, a $p$-value $\leq 0.05$ was considered statistically significant. The qualitative variables were expressed as frequency and percentage, while the quantitative variables were expressed as mean \pm standard deviation. The data were compared by the Pearson's chi-square test.

\section{RESULTS}

Of the 242 patients in the study, $77.9 \%$ (190 patients) were female and the mean age was 38 years. The mean body mass index (BMI) in the preoperative period was $41 \mathrm{~kg} / \mathrm{m}^{3}$, total cholesterol was $207 \mathrm{mg} / \mathrm{dL}$, LDL cholesterol was $118 \mathrm{mg} / \mathrm{dL}$,
HDL cholesterol was $49 \mathrm{mg} / \mathrm{dL}$, fasting glucose was $105 \mathrm{mg} / \mathrm{dL}$ and hemoglobin was $13.9 \mathrm{~g} / \mathrm{dL}$. Bioelectrical impedance analysis showed a mean value of $55 \%$ of lean body mass and $58 \%$ of fat body mass. In the postoperative period, the mean BMI was $27.3 \mathrm{~kg} / \mathrm{m}^{3}$, total cholesterol was $164 \mathrm{mg} / \mathrm{dL}$, LDL cholesterol was $90 \mathrm{mg} / \mathrm{dL}$, HDL cholesterol was $55 \mathrm{mg} / \mathrm{dL}$, fasting glucose was $80 \mathrm{mg} / \mathrm{dL}$ and hemoglobin was $13 \mathrm{~g} / \mathrm{dL}$. Postoperative bioelectrical impedance analysis showed a mean value of $49 \%$ of lean body mass and $52 \%$ of fat body mass.

The occurrence of reflux esophagitis (Graph 1) in the preoperative period was $81.1 \%$ (196 patients), including $68.5 \%$ (134 patients) grade A, 26.9\% (53 patients) grade B, 3.8\% (7 patients) grade $\mathrm{C}$ and $0.8 \%$ (2 patients) grade $\mathrm{D}$. In the postoperative period, $31.3 \%$ (75 patients) showed esophagitis, including $84.6 \%$ (63 patients) grade A and 15.4\% (12 patients) grade $B$, with no evidence of grade $C$ or $D$. There was no difference regarding the distribution of esophagitis severity between female and male patients.

With regard to bariatric treatment response to control moderate and severe esophagitis (grades B, C and D), there was a reduction in prevalence from $25 \%$ (62 patients) to $5 \%$ (12 patients) $(p<0.05)$. There was no statistically significant relationship between the percentage of weight loss or postoperative $\mathrm{BMI}$ and the occurrence of esophagitis, as well as between preoperative BMI and esophagitis severity.

Regarding secondary findings, the preoperative prevalence of hepatic steatosis was 78\% (188 patients), whereas in the postoperative period 14\% (34 patients) presented a mild degree of steatosis. Younger patients had higher levels of HDL cholesterol in the preoperative period $(p<0.05)$, with no evidence of difference in the postoperative period. Higher plasma levels of HDL cholesterol in the preoperative period were related to a greater magnitude of weight loss

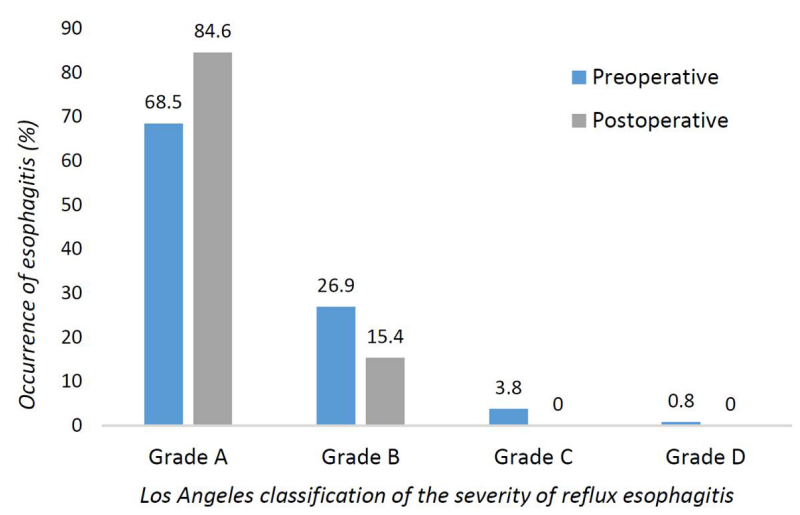

Graph 1: Occurrence of reflux esophagitis in the preoperative and postoperative periods. 
$(p<0.05)$. There was a positive correlation between reduced total cholesterol and increased lean body mass $(p<0.05)$. Preoperative plasma levels of LDL cholesterol were higher among the male patients $(p<0.05)$.

\section{DISCUSSION}

Esophagitis caused by GERD is a non-metabolic complication of obesity. The association between the two conditions is extremely relevant, with higher incidence of GERD in the obese population ${ }^{3}$ and higher recurrence rates of reflux disease in patients undergoing gastric fundoplication, mainly in those with a BMI greater than $35 \mathrm{~kg} / \mathrm{m}^{28,9}$. Although sleeve gastrectomy is currently the most commonly performed bariatric surgery in the world, exceeding the number of Roux-en-Y gastric bypass procedures, the former is associated with poorer GERD-related parameters, especially reflux esophagitis ${ }^{10-12}$.

In this study, the incidence of reflux esophagitis before bariatric surgery was $81.1 \%$, with variable degrees of esophagitis and with a high prevalence of moderate esophagitis. Gastric bypass was effective in the control of reflux esophagitis, being quite evident the regression in cases of moderate and severe esophagitis. An important improvement in GERD after bariatric treatment with the gastric bypass technique has been reported ${ }^{13-15}$, and the main mechanisms described to justify such improvement are the fact that the gastric pouch is small and has a lower acid production; weight loss leads to lower intra-abdominal pressure; and intestinal derivation improves biliary reflux. In this sample, no correlation was demonstrated between $\mathrm{BMI}$ - both preoperatively and postoperatively - and the degree of esophagitis.

The study also showed a significant improvement in metabolic parameters after bariatric treatment. There was a significant regression in the prevalence of hepatic steatosis and dyslipidemia. Serum HDL cholesterol levels in the preoperative period were associated with greater weight loss after bariatric surgery. In the postoperative period, serum glucose and LDL cholesterol levels reduced while HDL cholesterol levels increased, which is consistent with the finding of other studies ${ }^{16}$.

\section{CONCLUSION}

Bariatric surgery using the Roux-en-Y gastric bypass technique is effective in the control of reflux esophagitis. Regression is observed mainly in cases of moderate and severe esophagitis.

RouX-en-Y gastric bypass leads to a significant improvement in metabolic and anthropometric parameters, significantly reducing the plasma levels of LDL cholesterol and glucose as well as increasing $\mathrm{HDL}$ cholesterol. The postoperative reduction in BMI reveals that the technique can promote weight loss.

\section{Conflicts of Interest}

The authors declare no conflicts of interest.

\section{REFERENCES}

1. Siegrist PW, Krejs GJ, Blum AL. Symptoms of gastro-oesophageal reflux (author's transl). Dtsch Med Wochenschr. 1974;99(42):2088-94. PMid:4426226.

2. Hampel $\mathrm{H}$, Abraham NS, El-Serag HB Meta-analysis: obesity and the risk for gastroesophageal reflux disease and its complications. Ann Intern Med. 2005;143(3):199-211. PMid:16061918.

3. Eusebi LH, Ratnakumaran R, Yuan Y, Solaymani-Dodaran M, Bazzoli F, Ford AC. Global prevalence of, and risk factors for, gastro-oesophageal reflux symptoms: a meta-analysis. Gut. 2018;67(3):430-40. PMid:28232473.

4. Wilson LJ, Ma W, Hirschowitz BI. Association of obesity with hiatal hernia and esophagitis. $A m \mathrm{~J}$ Gastroenterol. 1999;94(10):2840-4. PMid:10520831.
5. Pandolfino JE, El-Serag $\mathrm{HB}$, Zhang Q, Shah N, Ghosh SK, Kahrilas PJ. Obesity: a challenge to esophagogastric junction integrity. Gastroenterology. 2006;130(3):63949. PMid:16530504.

6. Vries DR, van Herwaarden MA, Smout AJ, Samsom M. Gastroesophageal pressure gradients in gastroesophageal reflux disease: relations with hiatal hernia, body mass index, and esophageal acid exposure. Am J Gastroenterol. 2008;103(6):1349-54 PMid:18510603.

7. Stene-Larsen G, Weberg R, Froyshov Larsen I, Bjortuft O, Hoel B, Berstad A. Relationship of overweight to hiatus hernia and reflux oesophagitis. Scand J Gastroenterol. 1988;23(4):427-32. PMid:3381064.
8. Perez AR, Moncure AC, Rattner DW. Obesity adversely affects the outcome of antireflux operations. Surg Endosc. 2001;15(9):986-9. PMid:11443428.

9. Morgenthal CB, Lin E, Shane MD, Hunter JG, Smith CD. Who will fail laparoscopic Nissen fundoplication? Preoperative prediction of longterm outcomes. Surg Endosc. 2007;21(11):1978-84. PMid:17623236.

10. Del Genio G, Tolone S, Limongelli $P$, Brusciano L, D'Alessandro A, Docimo G, et al. Sleeve gastrectomy and development of "de novo" gastroesophageal reflux. Obes Surg. 2014;24(1):71-7. PMid:24249251.

11. Burgerhart JS, Schotborgh CA, Schoon EJ, Smulders JF, van de Meeberg PC, Siersema PD, et al. 
Effect of sleeve gastrectomy on gastroesophageal reflux. Obes Surg. 2014;24(9):1436-41. PMid:24619293.

12. Toro JP, Lin E, Patel AD, Davis SS JR, Sanni A, Urrego HD, et al. Association of radiographic morphology with early gastroesophageal reflux disease and satiety control after sleeve gastrectomy. J Am Coll Surg. 2014;219(3):430-8. PMid:25026879.

13. Madalosso CA, Gurski RR, Callegari-Jacques SM, Navarini D, Thiesen V, Fornari F. The impact of gastric bypass on gastroesophageal reflux disease in patients with morbid obesity: a prospective study based on the Montreal Consensus. Ann Surg. 2010;251(2):244-8. PMid:20010088.

14. Madalosso CA, Gurski RR, CallegariJacques SM, Navarini D, Mazzini G, Pereira MS. The impact of gastric bypass on gastroesophageal reflux disease in morbidly obese patients. Ann Surg. 2016;263(1):110-6. PMid:25607766.
15. Miguel GP, Azevedo JL, Souza PH, Siqueira J No, Mustafa F, Zambrana ES, et al. Erosive Esophagitis after Bariatric Surgery: Banded Vertical Gastrectomy versus Banded Rouxen-Y Gastric Bypass. Obes Surg. 2011;21(2):167-72. PMid:21108021.

16. Lira NS, Macedo CES, Belo GM, Santa-Cruz F, Siqueira LT, Ferraz $A A B$. Analysis of the lipid profile of patients submitted to sleeve gastrectomy and Roux-en-Y gastric bypass. Rev Col Bras Cir. 2018;45(6):e1967.

Received: Mar 21, 2019 Accepted: June 24, 2019 